\title{
INVESTIGATION OF THE MAINTENANCE ORGANISATION FOR HOT ROLLING MILLS
}

\author{
PG Pretorius and JK Visser \\ Department of Engineering and Technology Management \\ University of Pretoria \\ Pretoria 0002, South Africa \\ E-mail: krige.visser@eng.up.ac.za
}

\begin{abstract}
Production systems have undergone dramatic changes in recent years. Many companies have implemented new technologies such as flexible manufacturing systems. There is therefore a shift in focus to maintenance and the effective management thereof. Maintenance is a dynamic activity and is comprised of a large number of interacting variables. An effective maintenance organisation is required to control these variables.
\end{abstract}

This paper discusses the building of a maintenance organisation and the aspects that should be considered during the design. The way in which five companies that operate hot rolling mills approached the problem of building an effective maintenance organisation was investigated.

\section{OPSOMMING}

Vervaardigingstelsels het drastiese veranderinge ondergaan die afgelope aantal jaar. Verskeie maatskappye maak nou gebruik van nuwe tegnologicë, soos byvoorbeeld aanpasbare vervaardigingstelsels. Daar is gevolglik ' $n$ verskuiwing in fokus na instandhouding en die effektiewe bestuur daarvan. Instandhouding is ' $n$ dinamiese aktiwiteit en behels ' $n$ groot aantal gekoppelde veranderlikes. ' $n$ Effektiewe instandhoudingsorganisasie word benodig om hierdie veranderlikes te beheer.

Hierdie artikel bespreek die daarstelling van die instandhoudingsorganisasie en die parameters wat oorweeg moet word tydens die ontwerp. Die wyse waarop vyf maatskappye wat warmwaise bedryf die ontwikkeling van 'n effektiewe organisasie vir instandhouding benader het is ondersoek. 


\section{Introduction}

Raouf and Ben-Daya [1] stated that product life cycles are decreasing because today's market conditions are characterised by an increase in emphasis on variety, quality and delivery performance. In the past, quality acted as an order winner but this has now changed. Presently, quality is accepted by customers as a given and has become an order qualifier. The realisation of what was happening in the market place came as a shock to many companies and many of these companies were faced with a decline in sales and a diminishing customer base.

Other companies realised what was happening and responded to these new requirements by turning to high technology equipment and strategies such as flexible manufacturing systems. Many organisations have adopted new manufacturing methodologies, for example Just-InTime (JIT) delivery of inventory and much focus is placed on reducing set-up and adjustment times.

These factors have shifted the focus to maintenance and the effective management thereof The reason for this is that all these philosophies and strategies are based on the assumption that the production equipment has a high availability. The result is that many existing and new high technology organisations are giving increased attention to maintenance. This has resulted in an increase in the proportional size of the maintenance effort compared to the operating group.

According to Niebel [2], the typical size of a maintenance group in a manufacturing organisation ranged from $5-10 \%$ of the operating force ( 1 to $17 \%$ in 1969 and 1 to $12 \%$ in 1981). The size of maintenance departments has now increased due to the already mentioned mechanisation and automation of the manufacturing equipment and the accompanying processes. The higher level of automation has resulted in a greater demand for maintenance workers (artisans). At the same time, the demand for operators has decreased.

Maintenance is a dynamic activity and is comprised of a large number of interacting variables. This interaction sometimes takes place in a random pattern. Organisations are organising and structuring their maintenance function in such a way to best manage these changes.

The maintenance organisation or function in any industry or business is faced with the same common problems confronting manufacturing management in the production of a competitively priced product. The maintenance department is integrated with other departments of the organisation and is a structured activity whose main product is service. As described by Kelly [3], the function of the maintenance department is the ensuring and controlling of the reliability of the plant. The objective of the maintenance function should be compatible with the production and corporate objectives.

The strategy selected for this research is the Business Centered Maintenance approach. This is a generic approach best suited for process plants and uses well-established administrative management principles. 
One of the challenges of maintenance is to deliver a competitively priced product in the form of a service to the organisation that enhances its ability to make a profit. Maintenance employees are highly paid people and the percentage of time spent performing useful maintenance work is typically low. Maintenance resources are increasing and it is important for a business or industry to be competitive by means of a sound engineered maintenance management strategy and program.

\section{Building the Maintenance Organisation}

\subsection{The Business Centered Maintenance Approach}

The Business Centered Maintenance (BCM) approach to maintenance strategy development, as developed by Kelly [3], is based on the following steps illustrated in figure 1 .

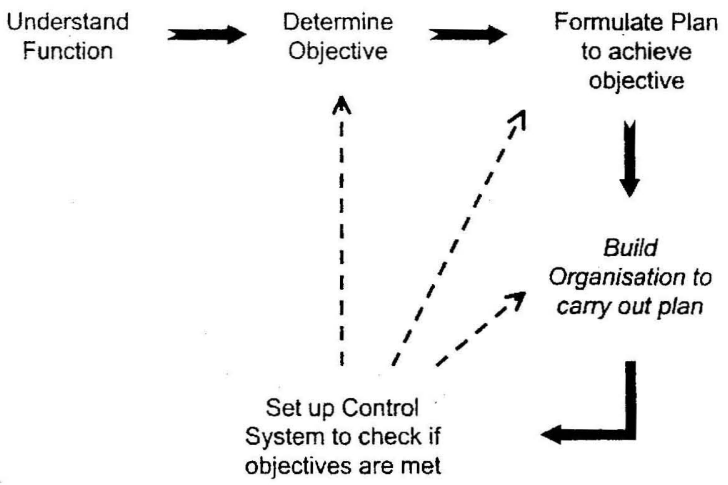

\section{Figure 1: The basic steps of the management process}

The primary task of the maintenance organisation is to match the resources to the workload in such a way that the agreed plant output is achieved at minimum resource cost. The organisational design should aim at maximising the performance of the maintenance workers. The main elements of the maintenance organisation are illustrated in the following diagram that was developed by Kelly [3]. 


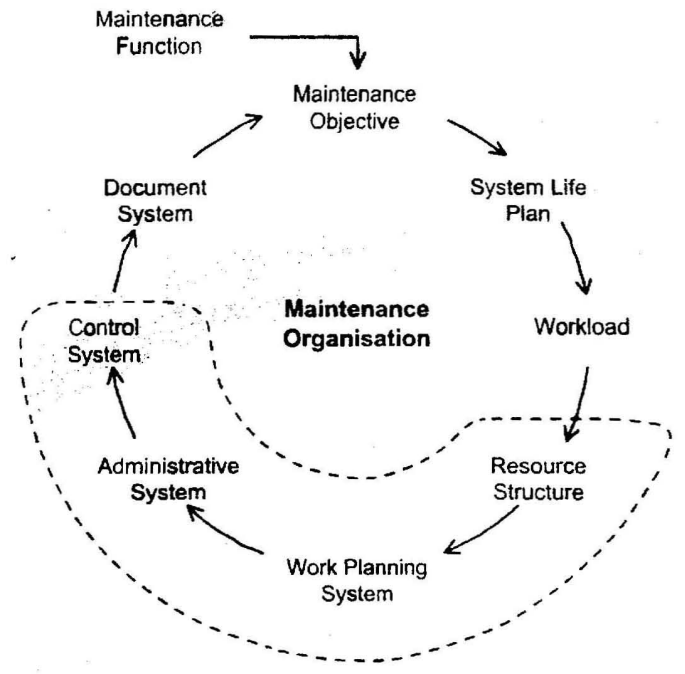

Figure 2: The main elements of the maintenance organisation (from Kelly [3])

The methodology for development of a maintenance strategy is initiated with the objectives of the organisation. From figure 2, it can be seen that the workload, which is a function of the company objective, forms a direct input to the maintenance organisation process.

One of the features of the methodology suggested by Kelly [4] for the development of the maintenance strategy is the top-down-bottom-up (TDBU) process. External (top-down) as well as internal (bottom-up) factors have a direct influence on the design of the maintenance organisation of a company. Kelly [3] listed the following external and internal factors that can influence the design of the maintenance organisation.

\begin{tabular}{|c|c|}
\hline External & $\begin{array}{l}\text { - Production organisation } \\
\text { - Human resource management policy } \\
\text { - Trade union agreements }\end{array}$ \\
\hline Internal & $\begin{array}{l}\text { - Workload } \\
\text { - Life plan and schedule } \\
\text { - Plant layout and technological sophistication }\end{array}$ \\
\hline
\end{tabular}

Table 1: Influences on the maintenance organisational design (from Kelly [3])

\subsection{The Maintenance Workload}

It can be seen from figure 2 that the maintenance workload does not form part of the maintenance organisational component. The nature of the maintenance workload greatly 
influences the structure of the maintenance organisation. One of the challenges a company or organisation is faced with is to forecast and map the required workload. Before an organisation attempts to forecast the required workload, it needs to understand and examine the characteristics of the workload relevant to its application. One of the major characteristics of the maintenance workload is the percentages of preventive and corrective work. A third less important category is modification maintenance. A next level breakdown of these types of maintenance is shown in table 2 .

\begin{tabular}{|c|c|}
\hline Corrective & $\begin{array}{l}\text { - Emergency } \\
\text { - Deferred } \\
\text { - Workshop }\end{array}$ \\
\hline Preventive & $\begin{array}{l}\text { - } \text { Routine (on-line) } \\
\text { - Services } \\
\text { - Major }\end{array}$ \\
\hline Modification & $\begin{array}{ll}\text { - } & \text { Revenue } \\
\text { - } & \text { Capital }\end{array}$ \\
\hline
\end{tabular}

Table 2: Division by policy characteristics (from Kelly [3])

Maintenance work can also be classified according to organisational characteristics as indicated in table 3 .

\begin{tabular}{|c|c|}
\hline First line & $\begin{array}{l}\text { - Corrective emergency } \\
\text { - Corrective deferred } \\
\text { - Preventive routine }\end{array}$ \\
\hline Second line & $\begin{array}{l}\text { - } \text { Corrective deferred } \\
\text { - } \text { Corrective workshop } \\
\text { - Preventive services } \\
\text { - } \quad \text { Modifications (minor) }\end{array}$ \\
\hline Third line & $\begin{array}{ll}\text { - } & \text { Corrective deferred } \\
\text { - } & \text { Preventive major } \\
\text { - } & \text { Modification (major) }\end{array}$ \\
\hline
\end{tabular}

Table 3: Division according to organisational characteristics

Forecasting a maintenance workload for a new plant or technical system is a difficult exercise. Here the company must rely on management experience, manufacturer's information and experience of a similar plant. Where possible the company can make use of benchmarking or information from a technological partner to forecast the workload. Although the forecast is only a best estimate, it will assist to set up and plan the initial maintenance organisation. 


\subsection{Maintenance resource structure}

The first element of the maintenance organisation is the maintenance resource structure. Kelly [3] defines the maintenance resource structure as that part of the maintenance organisation that is 'concerned with the geographical location of personnel, tools, spares and information; their function, composition and size; and their logistics'. Different levels of maintenance can be identified. The required levels are dependent on the operating characteristics and the objective of the organisation. An organisation operating on a 24-hour shift pattern basis will normally employ first line maintenance teams that perform mainly reactive work. Day shift artisans can make up the second line while a third line can be formed by a centralised workshop.

The following steps to determine a resource structure for a new plant is outlined by Kelly [3].

- Understand the resource characteristics

- Draw a plant layout and estimate the composition, size and pattern of the workload arising from each plant and trade and categorise this into first, second and third line work

- Determine the level of response the production will find acceptable

- Formulate the maintenance workforce structure

Due to the uncertainty in the size and pattern of the workload for a new plant, it is important to structure the workforce in a conservative way. One should restrict the size of the permanently employed workforce until experience has been gained.

\subsection{Maintenance Administrative Structure}

The second element of the maintenance organisation structure is the administrative structure. Kelly [3] defines the maintenance administrative structure as a 'complex of managerial roles for deciding when and how an industrial plant should be maintained'. There is a distinct difference between the maintenance resource structure and the maintenance administrative structure. The maintenance administrative structure is concerned with the allocating of the responsibility for carrying out the work whereas the resource structure is concerned with the composition and location of the resources.

The maintenance administrative structure forms the decision-making part. It can be viewed as a hierarchy of work roles, ranked by authority and responsibility, for deciding what, when and how maintenance work should be carried out. The organisation chart can be used as modeling vehicle to illustrate in a graphical format how work roles are inter-linked. Raouf and BenDaya [1] says that a well-defined maintenance department organisation is essential to a productive maintenance activity. The organisation should take into consideration the following important issues:

- Appropriate ratio of supervisors to workers

- Proper number of planners

- Necessary support functions 


\subsection{The work planning system}

The third element in the design of a maintenance organisation is the formation of the maintenance systems. The most important part of the maintenance system is the work planning system. Kelly [3] defines the work planning system as 'the way in which maintenance work is planned, scheduled, allocated and controlled'. The work planning system is unique for each company or technical system. The following aspects should be taken into account for the design of a work planning system for maintenance:

- it should be based on the maintenance resource structure

- it should allow job requests to flow to the best level or planning, scheduling and controlling

- a set of job priority rules should be defined

- the function, responsibility, and lines of communication between each of the planning levels must be clearly defined

- the right information concerning the workload and the resources must be available

- the maintenance planner should have the authority to take certain decisions

\subsection{The Control System}

The fourth element of the maintenance organisation is the control system. The control system is needed to ensure that the maintenance organisation is achieving its objectives and to provide the necessary corrective actions. Typical corrective actions would include changing the number of maintenance workers, the type and number of spares held in store, etc. Kelly [3] points out three principle aspects of control within the maintenance environment, namely:

- the control of the maintenance productivity

- the control of the maintenance effectiveness

- the control of the maintenance organisational efficiency

\section{Discussion of Research Results}

\subsection{Background}

The aim of the research was to establish what the building of a maintenance organisation comprises, and how various steel and aluminium producers in industry approach the organisation of the maintenance resources effectively.

Five different steel and aluminium producing plants around the world were selected as case studies. The five companies were chosen randomly and are therefore not representative of the industry in general. However, these five plants do provide a snapshot of how industry in 
various countries address the problem of organising the maintenance resources. The conclusions that are given later are therefore only applicable to the five case studies at hand. However, some of the principles can be applied to steel and aluminium producers in general.

\subsection{Characteristics of the hotmills}

Five hotmills that compete in two different but related industries namely that of steel (which include stainless steel) and aluminium were investigated. Three of these hotmills are situated in South Africa, one in the United States of America and one in Japan. Some of the characteristics of the five hotmills are given in table 4 .

\begin{tabular}{|l|l|l|l|l|}
\hline \multicolumn{1}{|c|}{ Hotmill } & \multicolumn{1}{|c|}{ Country } & \multicolumn{1}{|c|}{ Type } & \multicolumn{1}{c|}{$\begin{array}{c}\text { Marketing } \\
\text { Focus }\end{array}$} & \multicolumn{1}{|c|}{ Sophistication } \\
\hline Alcan Oswego & USA & Steel & Domestic & Mixed \\
\hline Columbus Stainless & RSA & Stainless steel & Export & State of the art \\
\hline $\begin{array}{l}\text { Highveld Steel and } \\
\text { Vanadium }\end{array}$ & RSA & Stainless steel & Export & Low to mixed \\
\hline Huletts Aluminium & RSA & Aluminium & Export & State of the art \\
\hline Sky Aluminium & Japan & Aluminium & Domestic & Low to mixed \\
\hline
\end{tabular}

\section{Table 4: Characteristics of the hotmills investigated}

Three of the plants have been in operation for more than or close to thirty years, one was commissioned four years ago and another has just been completed. These plants are therefore in various stages of their equipment life cycles.

The five plants have more or less the same output volume, with the exception of the Alcan Oswego plant in the USA. The increase in output of this plant was achieved through continuous upgrade of existing equipment. The other plants have been commissioned with the output capacity it has at present.

The five companies compete in different markets. The two overseas companies focus mainly on their domestic market. The three companies in South Africa have their main focus on export but also deliver part of its output capacity to its local or domestic market. The difference is however that in the case of local supply, these companies are the sole suppliers of the product in question in the local market.

The technological sophistication of the plants varies from very low to very sophisticated. The sophistication relates to the level of automation and control. In most cases, the equipment in the older plants has been upgraded on a continuous basis or new equipment has been added to increase the output capacity. The equipment upgrade focused on three main areas:

- Increase in volume throughput capabilities

- The level of equipment automation

- The accuracy of its control capability, i.e. feedback and feed-forward control 
With exception of the two new plants, the rest of the plants are subjected to very high levels of utilisation. The plant with the highest utilisation levels by far is that of the Alcan Oswego followed by Sky Aluminium and Highveld Steel and Vanadium. The two new plants are subjected to a planned and controlled ramp up in production and are both at the desired levels of utilisation.

The average percentage of breakdowns varies between the plants. The older plants seem to be more stable and most of the reliability problems have been solved. The Sky Aluminium plant has a very low average breakdown rate of $1,5 \%$. On the other end of the scale, we find Huletts Aluminium with an average breakdown rate of $20 \%$ for the year 2000 . This high rate can be attributed to the wear in phase of most of the new equipment and design problems that had to be addressed.

The total number of employees in the various companies differs largely. Of interest here is the trend that is occurring in plants with respect to the number of employees that were employed a few years back and the total number today. In all five cases, far less employees carry out the same and even more work. The older plants also have on average more employees. This is also the case when one has a look at the maintenance personnel. The ratio between maintenance and production personnel has increased dramatically. This can be attributed to the fact that the higher level of automation results in a lower need for operating personnel. The opposite is true for the maintenance personnel. More highly skilled artisans, technicians and engineers are required to maintain the sophisticated equipment.

The companies were in general reluctant to provide much information on their maintenance budgets. In many instances, they see it as a competitive advantage. The total maintenance costs for the hotmills in question varied from $7 \%$ to $38 \%$. The labour component of these budgets is in the region of $13 \%$ to $19 \%$. The variation can be attributed to the fact that the five plants all produce different commodities that result in different cost structures.

All the plants use availability as one of their main indicators of maintenance performance. Availability is complemented with the normal indicators like costs, resource utilisation, etc. The indicators are generally seen in isolation but as part of the bigger picture. It is valued on the same level as quality, throughput, etc. Columbus Stainless also uses Overall Equipment Effectiveness (OEE) as an indicator for maintenance and production performance.

\subsection{Maintenance strategies}

The maintenance strategies that are applied at all five plants differ largely. What is however interesting to note is that there is much similarity in concepts and strategies but that these strategies are applied differently.

An analysis of the trend in maintenance strategy development clearly shows that for the cases in question the move is in introducing some of the fundamental building blocks of Total Productive Maintenance (TPM). The aspect that is highlighted is that of teams consisting of operators and maintenance personnel taking responsibility for all aspects of production and maintenance on a section of equipment or shift basis. In the older plants, the opposite is true but they are still reasonably successful. The relationship between maintenance strategy and the plant performance is not a clear-cut one. 
The following trends in maintenance strategies can be highlighted:

- Alcan Oswego - The plant is more than 30 years old. Maintenance and production is separated on a very high level and RCM plays and important role.

- Columbus Stainless. The plant is now five years old. First and second line maintenance and production are fully integrated on shift basis. RCM and QS 9000 principles are used.

- Highveld Steel and Vanadium - The plant is about 30 years old. Maintenance and production is separated at a high level. This is a typical example of an older type of structure.

- Huletts Aluminium - The plant is two years old. The plant is organised as a team with production and maintenance specialists. A combination of maintenance strategies is used and one could express this as machine centered maintenance.

- Sky Aluminium - The plant is now 30 years old. First line maintenance and production is fully integrated. The fundamental principles of TPM are used.

\subsection{The Maintenance workload}

All the companies that were investigated in this research divide their workload with the aid of organisational characteristics. Each company handles the breakdown of these organisational characteristics in a different way. The first line maintenance may for instance be incorporated into the production function in one structure whereas in the next it is a totally separate maintenance function that has no influence or connection with production, apart from keeping the plant going. The way in which the characteristics are handled is different but they are all present in the companies in question.

The maintenance workloads for the various plants are determined more or less in a similar way. In the older plants ( 30 years or older) the workload is based on history of the maintenance performance of the equipment and the plant. In most of these older plants experienced gained by technological partners are also used. In the companies that are part of a larger group, they also base their workload on the experience of similar equipment within the group.

The maintenance workload for the two new plants in the study is based on the experience of technological partners, the recommendations of the equipment suppliers and limited use of the RCM and FMECA analysis techniques.

All of the plants state that they believe in preventive and planned maintenance. Equipment is inspected and restored on scheduled intervals. The equipment is either repaired or upgraded in position or removed from the plant and repaired and replaced. In the two newer plants a great shift in emphasis is made to the use of Condition Based Maintenance techniques where the restoration and work plan is based on the condition of the equipment as opposed to predetermined fixed intervals. 


\subsection{Maintenance resource structure}

Earlier on, it was indicated that the maintenance resource structure could be divided into three areas of interest, namely:

- Mapping the resource structure

- A model of the resource structure

- The resource characteristics and key decision-making areas of the resource structure

When we investigate the first aspect of the maintenance resource structure, we see that all of the plants in this investigation have more or less the same process layout due to the similarity of the rolling process employed. The difference between the various mills can be attributed to the following factors:

- The type of commodity that is being hot rolled in the plant in question

- The capacity of the plant in question

- Whether the plant has undergone any expansion projects

The second area of interest in the resource structure is the resource structure itself. An investigation of the various resource structures reveals that all of the plant structures have certain aspects that are similar while others are totally different.

The last point of interest in this section is that of resource characteristics and the key decisionmaking areas of resource structuring. The key points that were investigated within the various hot lines were the manpower, spare parts, tools, information, contract labour, tradeforce composition, plant specialisation, workforce location, non-daywork maintenance cover and the size of the workforce.

All these aspects are being covered by the resource structures that are in place in the various organisations. The exact way they are set-up however differs from one hotline to another. The reason for this difference can be attributed to the following:

- The company culture and production strategy

- The company maintenance strategy and policy

- The physical layout of the plant

\subsection{Maintenance administrative structure}

The maintenance administrative structures of the five hot rolling mills are all different. Although the same positions are present in most of the structures, the relationships between them differ in all five the cases. This can be attributed to the fact that the company strategies, maintenance policy/philosophy and the company culture all differ. 
Alcan Oswego - Maintenance and production is divided up to the level of works manager. The result is that there exists a high level of vertical polarisation between the two functions. This is an example of the typical maintenance/production relationship in western plants a few years back. The decision-making between production and maintenance takes place on a very high level and the interaction on the floor is limited.

Columbus Stainless - The belief in the company and more specifically the rolling mill is that the heartbeat of production is on shift and this is where the resources should be focused. This is also reflected in their administrative structure. The team manager on shift takes full responsibility for the production and maintenance functions. This structure is by far the most integrated one of the five. The integration is right down to the shop floor. The company only recently made the change and it is difficult to judge the long-term success of the structure.

Highveld Steel and Vanadium - This structure is integrated on plant manager level. One feature of this structure is the number of layers within the structure. Both the maintenance and production structures are top heavy. The company recently started a drive to reduce the number of employees in the company. The first employees that were affected were the ones on the shop floor. Their numbers were reduced but the structures remained unaltered. This structure is also an example of how western steel producers were doing it in the past.

Huletts Aluminium - The company as a whole had a radical restructuring in the past few years. The company used the opportunity created with the expansion project to break down the barriers between the three "silos" that existed in their company structure. The philosophy is to create teams responsible for manufacturing areas that are self-sufficient and have the autonomy to make the decisions required to produce the product required. One important aspect of the company and more specific the hot line structure is the limited number of management layers and the small number of maintenance and production employees. Production and maintenance is also integrated on plant manager level. The plant manager is directly responsible for the production function and the shift process co-ordinators report directly to him. Another feature of this structure is the amount of outsourcing that is taking place for certain maintenance services.

Sky Aluminium - The approach used by this company is typically the ones prescribed and recommended by the Total Productive Maintenance practitioners. Although the company has no formal TPM implementation plan, they 'naturally' follow the principles thereof. First line maintenance is fully integrated into the production function. The maintenance down time prevention is by far superior to all the other plants researched.

\subsection{The work planning and control system}

The last part of the maintenance organisation of interest is that of work planning and control. This forms the dynamics of the maintenance organisation. The planning roles and responsibilities of the various organisations differ. It is interesting to note that the flatter the structure, the more the responsibility lies with the artisan on the shop floor to do his own planning and organising of his work. In some of the cases, it was also found that no dedicated planners were part of the structure. 


\section{Conclusion}

This research was limited to five hot rolling lines and it is therefore not possible to come to conclusions and try to generalise any results and findings for the steel or aluminium industry, or the manufacturing industry in general. However, there are some general principles that were mentioned in the literature survey that are true for the building of the maintenance organisation of any company, irrespective of the type of industry.

The maintenance organisation comprises of the following four main elements [3]:
1) Resource structure
2) Administrative structure
3) Work planning system
4) Control system

The workload for the plant forms a very important input to the resource structure determination. In all five plants/organisations that were analysed, these four main elements of the maintenance organisation were present. The way in which these elements are applied in the various hot lines are different. The following reasons can be given for the difference in approach:

- The background of the company, including the time in production

- The existing culture within the company

- The maintenance and production philosophy, i.e. the operational philosophy of the company

- The technological sophistication of the plant, including the stage in the plant life cycle

- The involvement of unions in the company

- The physical layout of the plant

- The maintenance strategy followed

The systems philosophy states that the performance of a system is a function of the performance of its elements as well as the way in which these elements interact with each other. The organisational structure determines the way in which subsystems of the enterprise, i.e. divisions, departments and sections, interact with each other to determine the overall performance of the business enterprise. One feature of Columbus Stainless steel is that an integrated organisational structure is used. This has certainly contributed towards winning the Maintenance Excellence Award of the Southern African Maintenance Association in 2000 and 2001.

It can be concluded that the Business Centered Maintenance (BCM) approach proposed by Kelly [3] is generally applicable to the maintenance organisation of a hotline, as was 
illustrated by the five case studies. It is however important to note that the application will differ from one company to another due to the reasons listed above.

\section{References}

[1] Raouf, A. and Ben-Daya, M., 1995, "Total Maintenance Management: a Systematic Approach", Journal of Quality in Maintenance Engineering, 1, (No 1), p6-14

[2] Niebel, B.W., 1994, "Engineering Maintenance Management", Second Edition, Marcel Dekker Inc.

[3] Kelly, A., 1997, "Maintenance Organisations and Systems", First Edition, ButterworthHeinemann, Oxford

[4] Kelly, A., 1997, "Maintenance Strategy", First Edition, Butterworth-Heinemann, Oxford 